\title{
Methyl groups or additional aromatic groups donate tumour promoting activity
}

\author{
E BOYLAND
}

From the TUC Centenary Institute of Occupational Health, London School of Hygiene and Tropical Medicine, London WCIE 7HT, UK

There are many examples in chemical carcinogenesis in which the introduction of methyl groups or aromatic rings increased the potency of polycyclic hydrocarbons and aromatic amines. Examination of the data in the light of the multistage process of carcinogenesis indicates that these groups convert initiators into complete carcinogens. As complete carcinogens have both initiating and promoting action, the added groups may be considered to have donated tumour promoting activity to the molecule. Such groups were once called "auxocarcinogens."

\section{Aromatic amines}

The demonstrations of the abilities of 0 -aminoazotoluene $^{2}$ and 4-dimethylaminoazobenzene, butter yellow, ${ }^{3}$ to induce liver tumour in rats have been frequently repeated. In one experiment the compound without methyl groups, 4-aminoazobenzene, also induced liver tumours in rats fed a low protein diet in which potatoes were the main constituent. ${ }^{4}$ In their experiment the first tumour was seen after 525 days. The carcinogenic action of aminoazobenzene was not seen again until it was shown that it was carcinogenic in young mice. ${ }^{5}$ 4-Aminoazobenzene was considered to be a tumour initiator. The rapid growth of the young animals provides the stimulus that can be provided by known tumour promoters. These experiments show that the addition of methyl groups, either to the amino group or certain positions of the aromatic ring, convert an initiator into complete carcinogens (figure). The methyl groups have therefore donated tumour promoting activity to the molecule. It is remarkable that methyl groups are specifically active; 4-diethylaminoazobenzene is not carcinogenic.

As 4-aminoazobenzene induced tumours in rats when the main constituent of the diet was boiled potatoes, it seems possible that the potato diet had some tumour promoting activity.

Received 1 April 1985

Accepted 15 April 1985

\section{Aromatic hydrocarbons}

In none of many experiments with phenanthrene did it alone produce tumours but when it was applied to the skin of mice before treatment with croton oil ${ }^{6}$ or TPA $^{7}$ the incidence of papillomas increased. Phenanthrene is therefore a tumour initiator. Two methyl derivatives 1,2,4-trimethylphenanthrene ${ }^{8}$ and 1,2,3,4-tetramethylphenanthrene ${ }^{9}$ were found to be weak but positive skin carcinogens.

Chrysene is a doubtful carcinogen. In an experiment a solution of $0.3 \%$ chrysene of "doubtful purity" was applied repeatedly to the skin of 50 mice producing two papillomas. ${ }^{10}$ These tumours could have been caused by other compounds in the material used. In many experiments pure chrysene was not carcinogenic. ${ }^{11}$ On the other hand, 5-methylchrysene is a potent skin carcinogen in mice. ${ }^{12}$

Benz(a)anthracene is a weak or "disputed" carcinogen but is mutagenic in many systems-for instance Salmonella typhimurium. ${ }^{13}$ It also acts as an initiator when its application is followed by treatment with croton oil. ${ }^{14}$ In this series the effect of addition of groups is most striking. The 7 and 12 monomethyl derivatives are definite carcinogens and 7,12-dimethylbenz(a)anthracene is the most rapidly acting carcinogen $^{15}$ - that is, the most potent tumour promotor of the complete carcinogens.

Benzene rings can have similar effects to methyl groups. Benzphenanthrene is a moderately active complete carcinogen and derivative of phenanthrene. Benzo(a)pyrene can be considered as a derivative of either chrysene or benz(a)anthracene.

\section{Conclusion}

Clearly in many cases the increase in carcinogenic activity that occurs on introduction of methyl groups into the molecule is due to increase in the tumour promoting rather than initiating activity. The biochemical basis for this effect is not clear. 7,12-Dimethylbenz(a)anthracene is metabolised to 7-hydroxymethyl-12-methylbenz(a)anthracene ${ }^{16}$ but 
Initiators

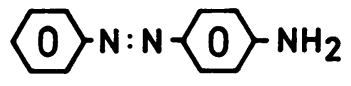

4-Aminoazobenzene

\section{Complete carcinogens}

0- $\mathrm{N}: \mathrm{N}-0-\mathrm{N}_{\mathrm{H}}^{\prime} \mathrm{CH}_{3}$

(0) $\mathrm{N}: \mathrm{N}-\mathrm{O}-\mathrm{N}\left(\mathrm{CH}_{3}\right)_{2}$

4-Dimethylaminoazobenzene

$0{ }^{\mathrm{CH}} \mathrm{N}-\mathrm{N}-\mathrm{NH}_{2}$

o Aminoazotoluene<smiles>Cc1cc(C)c2ccc3ccccc3c2c1C</smiles>

$1,2,4$

Trimethylphenanthrene

Tetramethylphenanthrene<smiles>Cc1cc2ccccc2c2ccc3ccccc3c12</smiles>

5-Methylchrysene<smiles></smiles>

7-Methylbenz [a] anthracene
$1,2,3,4$<smiles>Cc1c(C)c(C)c2c(ccc3ccccc32)c1C</smiles><smiles>Cc1c2ccccc2c(C)c2c(C)c3ccccc3cc12</smiles>

7, 12, Dimethylbenz [a] anthracene

Effect of methyl groups on carcinogenic activity.

this hydroxymethyl derivative is a slower carcinogen than the parent hydrocarbon. ${ }^{17}$

\section{References}

${ }^{1}$ Boyland E. The structure of chemical carcinogens. Acta Union International Contre le Cancer 1950;7:59-66.

${ }^{2}$ Yoshida T. Über die experimentelle Erzeugung von Hepatom durch die Fütterung mit O-Amido-azotoluol. Proceedings of the Imperial Academy of Japan 1932;8:464-7.

${ }^{3}$ Kinosita R. Researches on the carcinogenesis of various chemical substances. Gann 1936;30:423-6.

${ }^{4}$ Kirby AHM, Peacock PR. The induction of liver tumours by 4-aminoazobenzene and its $N$-N-dimethyl derivative in rats on a restricted diet. Journal of Pathology and Bacteriology 1947;59:1-18.

${ }^{5}$ Delcos KB, Tapley WG, Miller EC, Miller JA. 4-Aminoazobenzene and N-N-dimethyl-4-aminoazobenzene as equipotent hepatic carcinogens in male $\mathrm{SC} 7 \mathrm{BL} / 6 \mathrm{X}$ $\mathrm{C} 3 \mathrm{H} / \mathrm{HEF}_{1}$ mice and characterization of $\mathrm{N}$-(desoxyguanosin-8yl)-4-aminoazobenzene as the major persistent hepatic DNAbound dye in these mice. Cancer Res 1984;44:2540-50.

${ }^{6}$ Salaman MH, Roe FJC. Further tests for tumour-initiating activity: N,N-di(2-chloroethyl) p-aminophenyl butyric acid (CB 1348) as initiator of skin tumour formation in the mouse. $\mathrm{Br} J$ Cancer 1956;10:363-78.

${ }^{7}$ Scribner J. Tumor initiation by apparently non-carcinogenic polycyclic aromatic hydrocarbons. Journal of the National Cancer Institute 1973;50:1717-9.

${ }^{8}$ Butenandt A, Dannenberg $H$. Untersuchungen über die krebserzengende Wirkzsamkeit der Methyhomologen der 1,2-cyclopentophenanthrene. Archiv für Geschulstforschung 1953;6:1-7.

${ }^{9}$ Badger GM, Cook JW, Hewett CL, Kennaway EL, Kennaway NM, Martin RK. The production of cancer by pure hydrocarbons. Part V. Proc $R$ Soc Lond (B) 1940;129:439-67.

${ }^{10}$ Bottomley AC, Twort CC. The carcinogenicity of chrysene and oleic acid. Am J Cancer 1934;21:781-6. 
${ }^{11}$ Barry G, Cook JW, Haslewood GAD, Hewett CL, Heiger I, Kennaway EL. The production of cancer by pure hydrocarbons. Part III. Proc R Soc Lond (B) 1935;117:318-51.

${ }^{12}$ Hecht SS, Bondinell WE, Hoffmann D. Chrysene and methylchrysenes: presence in tobacco smoke and carcinogenicity. Journal of the National Cancer Instutute 1974;53:1121-33.

${ }^{13}$ McCann J, Choi E, Yamasaki E, Ames BN. Detection of carcinogens as mutagens in the Salmonella/microsome test: assay of 300 chemicals. Proc Natl Acad Sci USA 1975;72:5135-9.

${ }^{14}$ Roe FJC, Salaman MH. Further studies in incomplete carcinogenesis: triethylene melamine (TEM), 1,2-benzanthracene and $\beta$-propiolactone as initiators of skin tumour formation in the mouse. Br J Cancer 1955;9:177-203.

${ }^{15}$ Bachmann WE, Cook JW, Dansi a, et al. The production of cancer by pure hydrocarbons. Part IV. Proc $R$ Soc Lond $(B)$ 1937;123:343-68.

${ }^{16}$ Boyland E, Sims P. The metabolism of 7,12-dimethylbenz(a)-anthracene by rat liver homopenates. Biochem $J$ 1965;95:780-7.

${ }^{17}$ Dipple A. Polynuclear aromatic carcinogens. In: Searl CE, ed. Chemical carcinogens. Washington DC: American Chemical Society, 1976:245-323. (ACS monograph 173.)

\section{The October 1985 issue}

\section{THE OCTOBER 1985 ISSUE CONTAINS THE FOLLOWING PAPERS}

\section{Editorial}

Health assessment of applicants for nurse training J A LUNN

Cancer mortality of cadmium workers C-G ELINDER, T KJELLSTRÖM, C HOGSTEDT, $K$ ANDERSSON, AND G SPANG

Job load and hazard analysis: a method for the analysis of workplace conditions for occupational health care MK MATTILA

Body reactions during chain saw work T MATOBA, M CHIBA, AND T SAKURAI

A study of white finger in the gas industry D D WALKER, B JONES, S OGSTON, E G TASKER, AND A J ROBINSON

Influence of local vibration on plasma creatine phosphokinase (CPK) activity A OKADA, H OKUDA, R INABA, AND M ARIIZUMI
Diethyllead as a specific indicator of occupational exposure to tetraethyllead $\mathrm{Z}$ TURLAKIEWICZ AND J CHMIELNICKA

An outbreak of illness after occupational exposure to ozone and acid chlorides T P NG, T W TSIN, AND F J O'KELLY

Urinary screening for potentially genotoxic exposures in a chemical industry G AHLBORG JR, B BERGSTRÖM, C HOGSTEDT, P EINISTÖ, AND MARJA SORSA

Pulmonary response to agate dust in vivo and cytotoxic and haemolytic effects in vitro J L KAW AND M WASEEM

Kinetics of deposition and clearance of inhaled mineral dusts during chronic exposure J H VINCENT, A M JOHNSTON, A D JONES, R E BOLTON, AND J ADDISON

\section{Short report}

Tumour initiators, promoters, and complete carcinogens E BOYLAND

Book reviews

Copies are still available and may be obtained from the PUBLISHING MANAGER, BRITISH MEDICAL ASSOCIATION, TAVISTOCK SQUARE, LONDON WCIH 9JR 